\title{
Budaya Kerja dan Disiplin Kerja dalam Mewujudkan Kepuasan Kerja Pegawai di Sekretariat Daerah Kabupaten Agam
}

\author{
Malini Syaftia Rahmawati, Aldri Frinaldi \\ Magister Administrasi Publik, Universitas Negeri Padang, Jl. Prof. Dr. Hamka, Air Tawar Padang, 25132, Indonesia
}

\begin{tabular}{l}
\hline ARTICLE INFORMATION \\
\hline Received: February 24, 2021 \\
Revised: March 26, 2021 \\
Accepted: April 29, 2021 \\
Available online: April 24, 2021 \\
KEYWORDS \\
\hline Work Culture, Work Discipline, Job Satisfaction, \\
Regional Secretariat of Agam Regency. \\
CORRESPONDENCE \\
\hline Phone: +6281325906869 \\
E-mail: malinisyaftia24@gmail.com \\
\hline
\end{tabular}

\section{ARTICLE INFORMATION}

Received: February 24, 2021

Avili 24, 2021

Work Culture, Work Discipline, Job Satisfaction,

\section{PENDAHULUAN}

Pemerintah didefinisikan sebagai suatu organisasi yang terdiri atas kumpulan orang-orang yang dipilih melalui berbagai macam seleksi, yang berperan menjalankan tugas negara sebagai salah satu bentuk pelayanan kepada orang banyak. Pada saat ini, peranan sumber daya manusia termasuk salah satu faktor utama dan termasuk penting dalam organisasi baik swasta maupun negeri. Manusia yang dalam organisasi merupakan pegawai memiliki peranan yang penting dalam menentukan hidup atau matinya suatu oeganisasi. Pegawai sebagai unsur sumber daya manusai juga memiliki peran dalam menentukan keberhasilan penyelengaraan pemerintah dan pembangunan (Nawawi, 2006)

Dalam mewujudkan pegawai yang dapat bekerja untuk mencapai tujuan organisasi, maka dibutuhkan pegawai yang berkualitas secara berkelanjutan. Pegawai yang berkualitas diidentifikasi dengan adanya budaya kerja yang terarah, disiplin yang tinggi, sikap dan perilaku yang mencerminkan kesetiaan dan ketaatan penuh kepada negara, bermoral dan bermental baik dan sadar dengan tanggung jawab yang diemban sebagai pelayan publik. Pegawai yang berkualitas juga dapat diidentifikasi dari profesionalisme dalam bekerja (Mangkunegara, 2011).

Menurut Surat Keputusan Menteri Pendayagunaan Aparatur Negara dan Reformasi Birokrasi No. 39 Tahun 2012 tentang Pedoman Pengembangan Budaya Kerja yang didalamnya terdapat pedoman pengembangan budaya kerja yang dapat dipergunakan bagi Kementerian/Lembaga dan Pemerintah Daerah. Dalam melakukan suatu pekerjaan, kita di tuntut untuk selalu loyal terhadap tanggung jawab yang diberikan.

Budaya kerja dimaknai sebagai suatu landasan yang terdapat pada diri seseorang yang terlihat ataupun tidak terlihat yang dipandang berdasarkan perspektif nilai, pemahaman cara kerja, norma, pola pikir dan perilaku dalam menjalankan suatu pekerjaan baik secara individu ataupun secara berkelompok. Perspektif tersebut diperoleh dan dipengaruhi oleh nilai-nilai yang ada dalam masyarakat sebagai bentuk hasil interaksi individu dengan lingkungannya (Frinaldi, 2014). Seseorang yang bekerja baik secara individu maupun kelompok tidak akan pernah lepas dari budaya organisasi. Umumnya budaya yang muncul merupakan stimulus sehingga apabila individu dalam kelompok tersebut berperilaku akan memiliki spesifikasi dibandingkan dengan kelompok organisasi lain.

Pengimplementasian budaya kerja masih sangat komplek, karena masing-masing memiliki karakteristik yang berbedabeda. Budaya kerja menjadi sangat penting, karena dapat digunakan untuk memaksimalkan kerja pegawai sebagai nilai modal manusia yang mejadi manajemen kritis dalam kompetensi (Sinha, Singh, Gupta, \& Dutt, 2010). Budaya kerja sangat erat kaitannya dengan nilai dan lingkungan yang mengarah pada makna dan filosofi hidup yang mempengaruhi sikap dan perilaku seseorang di tempat kerja (Khuzaeni, 2013).

Apabila suatu organisasi memiliki budaya kerja yang bersifat positif, maka dalam organisasi tersebut akan terjadi sinergitas antara pegawai dan pimpinannya. Dengan demikian, pemimpin tidak akan tersita waaktu, pikiran dan tenaganya dalam menyelesaikan konflik antar pegawai (Frinaldi, 2014). 
Budaya kerja juga dapat dimaknai sebagai sendi mental yang terprogram yang membutuhkan tanggapan individu terhadap lingkungan hidup. Hal ini menyatakan bahwa setiap individu melihat budaya itu dengan jelas yang tergambar dalam perilaku sehari-hari. Namun hal tersebut dikendalikan oleh nilai-nilai yang terprogram dan tertanam dalam mental individu (Frinaldi \& Putri, 2020). Adapun tujuan budaya kerja adalah memelihara keserasian dan keharmonisan lingkungan kerja, menciptakan kondisi kerja yang teratur, tertib dan aman, memastikan pelaksanaan hak dan kewajiban kerja, memakmurkan dan mensejahterakan pekerja serta meningkatkan etos kerja yang tinggi dan dinamis (Frinaldi, 2014).

Budaya kerja dalam organisasi dapat dilihat dengan menggunakan dua komponen yaitu keyakinan yang menjadi nilai filosofi organisasi (guiding beliefs), yaitu merupakan seperangkat nilai yang dapat menjadi panduan bagi suatu organisasi guna melakukan adaptasi ekstenal dan memperoleh integrasi internal. Kedua, keyakinan operasi yang dilakukan (daily beliefs), yaitu merupakan satu set nilai yang dipraktekkan dalam melaksanakan pekerjaan harian dalam organisasi kemudian kebiasaan bekerja para staf itu menjadi budaya kerja khusus dari dalam suatu organisasi (Collins \& Poras, 1997). Daily belief merupakan suatu bentuk berbagai kebiasaan yang tampak dalam praktik kegiatan sebuah organisasi (Hofstede, 1997). Daily belie fjuga berarti sesuatu perbuatan yang menjadi praktik harian organisasi. Hakikatnya, setiap organisasi atau negara memiliki cara yang berbeda dalam melakukan suatu kegiatan dalam menyelesaikan permasalahan yang dihadapinya, sehingga makna budaya kerja positif dan budaya kerja negatif dari setiap negara itu berbeda (Frinaldi, 2014; Frinaldi \& Embi, 2013). Namun ada suatu tantangan yang cukup kompleks yaitu usaha yang dilakukan untuk mengubah budaya kerja lama yang sudah tidak sesuai lagi dengan nilai-nilai baru pada semua pegawai yang diubah dengan keinginan sukarela dan partisipasi diri tanpa ada paksaan.

Peraturan Bupati Nomor 18 Tahun 2017 tentang Kedudukan, Susunan Organisasi, Tugas, Fungsi dan Tata Kerja Sekretariat Daerah Kabupaten Agam bahwa Sekretariat Daerah yang berkedudukan dibawah dan bertanggungjawab kepada Bupati melalui Sekretaris Daerah, memiliki tugas membantu Bupati dalam penyusunan kebijakan dan pengkoordinasian administratif terhadap pelaksanaan tugas Perangkat Daerah serta pelayanan administratif.

Budaya kerja pada Sekretariat Daerah di Kabupaten Agam saat ini masih dinilai belum baik karena masih ada pegawai yang datang ke kantor hanya untuk absen pagi. Kemudian pergi meninggalkan kantor kemudian datang kembali ketika absen sore. Selain itu ada pegawai yang datangnya terlambat bahkan masih banyak pegawai yang keluar pada jam kerja untuk urusan pribadi. Hal ini jelas tidak sesuai dengan adanya budaya kerja yang bertujuan untuk menciptakan efektivitas dan efisiensi dalam bekerja.

Selain budaya kerja, disiplin kerja juga menjadi hal yang penting dalam bekerja di instansi pemerintahan. Disiplin kerja adalah salah satu hal penting yang perlu diperhatikan dalam melakukan suatu pekerjaan. Disiplin kerja dimaknai sebagai situasi yang dapat mendorong pegawai untuk melakukan kegiatan sesuai dengan norma atau peraturan yang telah ditetapkan. Bekerja secara disiplin itu berkaitan dengan ketaatan untuk melakukan tugas sesuai dengan aturan yang berlaku (Dwiyono, 2017). Dengan disiplin kerja yang baik pada diri pegawai, maka akan semakin tinggi prestasi kerja yang akan dicapainya.

Displin kerja merupakan perilaku kerja yang tumbuh berdasarkan kesadaran atas peran dan tanggung jawab terhadap organisasi. Disiplin kerja juga merupakan alat yang digunakan oleh atasan sebagai alat berkomunikasi dengan bawahan agar bersedia untuk mengubah perilaku dan ini juga merupakan salah satu upaya meningkatkan kesadaran dan kemauan agar mematuhi semua peraturan organisasi dan norma sosial yang berlaku (Susanty \& Baskoro, 2013).

Kedisiplinan adalah sikap sadar dan sedia seseorang untuk menaati semua peraturan dalam organisasi dan untuk menaati norma-norma sosial yang berlaku. sadar yang dimaksudkan adalah sikap seseorang secara sukarela untuk menaati semua peraturan dan sadar tentang tugas dan tanggungjawab yang dimilikinya. Sedia adalah sikap, tingkah laku dan perbuatan seseorang yang sesuai dengan peraturan secara tertulis dan tidak tertulis dalam organisasi (Hasibuan, 2013).

Pegawai dalam organisasi adalah penggerak kegiatan yang ada di dalam organisasi tersebut. Adapun yang harus diperhatikan pegawai dalam melaksanakan tugasnya adalah kepuasan kerja agar dalam pelaksanaannya sesuai dengan perencanaan organisasi sehingga dapat menciptakan efektivitas kerja yang baik. Untuk mencapai hal tersebut, maka perlu diadakan upaya yang maksimal untuk mendayagunakan sumber daya manusia yang dimiliki oleh organisasi untuk mendapatkan kepuasan kerja demi mencapai efektivitas kerja dalam organisasi. Kepuasan kerja merupakan salah satu faktor yang mendorong untuk meningkatkan menjelaskan kinerja pegawai yang pada akhirnya akan memberikan dampak pada kinerja organisasi (Gorda, 2004)

Pada dasarnya kepuasan kerja merupakan suatu kegiatan pengukuran sejauh mana kebutuhan pekerjaan terpenuhi dan seberapa banyak dari pemenuhan tersebut yang dirasakan oleh pegawai. Hal ini bisa dimaknai sebagai hal yang positif maupun negatif, karena hal tersebut merupakan penilaian evaluatif oleh seorang pegawai tentang pekerjaan dan situasi pekerjaan yang dirasakan (Weiss, 2002). Berdasarkan hal tersebut, maka kepuasan kerja merupakan salah satu bentuk hasil dari aspek yang diterima oleh pegawai dalam bekerja, baik berupa budaya kerja yang diterapkan termasuk disiplin kerja yang diterapkan dalam suatu organisasi.

Adanya permasalahan berupa budaya kerja yang tidak maksimal diterapkan dan adanya disiplin kerja yang tidak ditegakkan dengan tegas akan memberi dampak pada kepuasan masyarakat. Kepuasan kerja dijelaskan sebagai tanggapan afektif positif individu dan sikapnya terhadap pekerjaan mereka dan terhadap organisasi. Hal ini merupakan salah satu keadaan psikologis yang dirasakan oleh pegawai yang menyatakan bahwa kebutuhan mereka terpenuhi oleh organisasi (Chan, 2019). Kepuasan kerja dinikmati dalam pekerjaan, luar pekerjaan, dan kombinasi dalam dan luar pekerjaan. Ketika pegawai merasa bahwa pekerjaan mereka memberikan kontribusi yang berhasil bagi organisasi, maka mereka akan lebih termotivasi untuk bekerja dan mengalami kepuasan yang lebih besar seagai hasil dari penemuhan tanggung jawabnya sebagai pegawai (Lee, Willis, \& Tian, 2017). Pada intinya, kepuasan kerja itu mengacu pada penilaian evaluasi yanng dilakukan oleh seseorang terhadap pekerjaannya secara keseluruhan. Artinya, kepuasan itu dinilai dari kesukaan 
terhadap suatu pekerjaan, yang biasanya dibangun dari hal positif ke negatif (Judge, HM, Mueller, \& C.L, 2017).

Permasalahan yang terjadi pada Sekretariat Daerah Kabupaten Agam adalah kehadiran pegawai yang masih rendah, yang menjadi permasalahan dalam penegakkan disiplin kerja. Keterlambatan yang terjadi pada pegawai sampai saat ini belum bisa diatasi karena sampai sejauh ini sanksi hukuman yang tegas, jelas dan yang berkeadilan belum ditegakkan secara seutuhnya. Masih adanya keterlambatan para pegawai juga menjadi bukti bahwa belum adanya ketegasan yang baik dalam menerapkan kedisiplinan terhadap pegawai dalam bekerja.

Berdasarkan hasil observasi dan data yang peneliti dapatkan terkait kehadiran pegawai, jelas bahwa disiplin kerja pegawai masih rendah. Hal ini dapat dilihat dari rekapitulasi kehadiran pegawai yang diperoleh dari hasil input finger print kehadiran yang sudah menjadi standar pengukuran kehadiran di Sekretariat Daerah. Berdasarkan data yang diperoleh dalam penelitian berdasarkan obeservasi, dinyatakan bahwa persentase tingkat kehadiran pegawai pada setiap bagian sudah baik dengan rata-rata diatas $80 \%$.Akan tetapi keterlambatan masuk kerja atau cepat pulang kerja hampir dilakukan setiap hari oleh pegawai di sekretariat daerah 50\% hampir setiap bagian ada pegawai yang terlambat, dengan jumlah persentase terlambat setiap bagian mencapai $1-5$ orang. Tingginya persentase terlambat dapat menunjukkan bahwa disiplin pegawai terhadap jam kerja masih perlu ditingkatkan. Hanya saja adanya keterlambatan yang terjadi belum dapat diatasi, karena memang sampai sejauh ini sanksi hukuman yang tegas, jelas dan yang berkeadilan belum ditegakkan secara seutuhnya. Masih adanya keterlambatan para pegawai juga menjadi bukti bahwa belum adanya ketegasan yang baik dalam menerapkan kedisiplinan terhadap pegawai dalam bekerja.

Penelitian ini dilakukan untuk melihat pengaruh budaya kerja dan disiplin kerja terhadap kepuasan kerja pegawai. Kepuasan kerja pegawai dinilai menjadi hal yang sangat penting dan menjadi perhatian peneliti. Hal ini dikarenakan jika pegawai yang tidak mendapatkan kepuasan kerja, tidak akan mencapai kematangan psikologis. Akhirnya akan menyebabkan frustasi. Pegawai yang seperti ini akan sering melamun, mempunyai semnga kerja yang rendah, cepat lelah dan bosan, emosi tidak stabil, dan sering melakukan kesibukan yang tidak ada berhubungan dengan pekerjaan yang sering dilakukannya (Strauss \& Sayles, 2012). Penelitian ini merupakan penelitian yang dirancang untuk menguji pengaruh budaya kerja terhadap variabel dependen yang belum pernah dilakukan sebelumnya, yaitu terhadap kepuasan kerja. Karena kepuasan kerja menjadi hal yang sangat penting saat ini, mengingat pegawai merupakan aset terbesar organisasi dalam mencapai tujuan organisasi. Adapun pengaruh variabel budaya kerja dan disiplin kerja dalam penelitian ini akan dilihat pengaruhnya secara parsial dan simultan terhadap variabel kepuasn kerja. Hal ini bertujuan agar adanya akurasi data yang didapat, sehingga organisasi dapat mengoptimalkan variabel yang memiliki pengaruh besar terhadap kepuasan kerja.

\section{METODE}

Penelitian ini menggunakan metode kuantitatif dengan strategi survei. Strategi survei adalah strategi yang menjelaskan kecenderungan, sikap atau opini dari populasi secara kuantitatif (Creswell, 2010). Penelitian ini dilakukan di Sekretariat Daerah Kabupaten Agam. Adapun variabel dalam penelitian ini ada tiga, yaitu budaya kerja dan disiplin kerja sebagai variabel independen dan kepuasan kerja sebagai variabel dependen. Dalam penelitian ini, yang menjadi populasi adalah seluruh pegawai yang bekerja di Kantor Sekretariat Daerah Kabupaten Agam berjumlah sebanyak 151 orang. Sampel penelitian diambil dengan teknik total sampling atau disebut juga sampel jenuh, yang mana teknik penentuan sampel ini adalah seluruh anggota populasi. Teknik ini dipakai disebabkan jumlah populasi relatif kecil (Sugiyono, 2017). Data penelitian terdiri dari data primer dan data sekunder. Data primer didapatkan dari responden penelitian yang mengisi kuesioner. Sedangkan data sekunder diperoleh dari studi dokumentasi yang dilakukan di Sekretariat Daerah Kabupaten Agam. Data dalam penelitian ini dikumpulkan dengan teknik observasi dan kuisioner. Adapun instrumen yang digunakan untuk pengumpulan data adalah angket yang telah diuji validitas dan reliabilitasnya. Data yang telah terkumpul dilakukan analisis data. Analisis statistik deskriptif merupakan teknik analisa data yang digunakan dalam penelitian ini. Teknik ini menganalisis data dengan cara mendeskripsikan data yang terkumpul apa adanya dan tidak membuat kesimpulan yang berlaku secara umum (Sugiyono, 2013). Selanjutnya data yang telah terkumpul akan dilakukan analisis deskriptif dengan mengunakan Total Capaian Responden (TCR) yang selanjutnya akan dilakukan uji asumsi klasik sebagai syarat untuk melakukan analisis data regresi berganda. Ada dua uji yang dilakukan pada analisis regresi berganda, yaitu uji t atau yang disebut juga uji parsial dan uji $F$ yang disebut juga sebagai uji secara simultan.

Budaya kerja pegawai pada suatu organisasi dapat diukur menggunakan beberapa indikator (Frinaldi, 2017) yaitu (1) peran pemimpin, yang mengacu pada kuat atau lemahnya peranan pemimpin dalam pengamalan nilai-nilai yang dianut selama bekerja dalam organisasi; (2) penampilan, yang merupakan identitas seorang pegawai dalam bekerja di ruang publik; (3)kesadaran waktu, yang menyatakan bahwa pegawai mengerti bahwa dalam bekerja tidak ada tindakan untuk menunda-nunda pekerjaan; (4)komunikasi, yang berkaitan dengan kemampuan interaksi seseorang tehadap orang lain dalam menyampaikan pesan, sehingga yang menyampaikan dan yang menerima pesan memiliki pemahaman yang sama; (5)penghargaan dan pengakuan, sebagai bentuk wujud nyata apresiasi atas prestasi individu ataupun kelompok; (6) nilainilai yang diyakini, yag menyatakan keyakinan yang menjadi dasar bagi individu dalam bekerja.

Untuk mengukur dimensi disiplin kerja, ada beberapa indikator yang digunakan, seperti (Hasibuan, 2013) (1)tujuan dan kemampuan, dimana tujuan yang telah ditetapkan bersama diuraikan dalam beban kerja sesuai kemampuan pegawai; (2)teladanan pimpinan, yang mana pemimpin harus mencontohkan yang baik pada bawahan; (3)balas jasa, yang merupakan bentuk kesejahteraan yang diberikan oleh organisasi terhadap pegawai; (4)keadilan, adanya perlakuan yang sesuai dengan kondisi pegawai; (5)pengawasan melekat, yang mana pemimpin harus secara aktif dan langsung melakukan pengawasan terhadap perilaku, moral, sikap, gairah kerja, dan prestasi kerja pegawai (6)sanksi hukum, harus bersifat mendidik dan dapat dijadikan motivasi untuk menjaga dan memelihara kedisiplinan dalam organisasi; (7)Ketegasan, ynag merupakan bagian yang harus dimiliki oleh pemimpin, sehinngga tidak ada yang merasa diuntungkan atau dirugikan 
dalam pemberian sanksi; (8)hubungan manusia, adapun hubungan yang serasi dan sesuai akan mewujudkan lingkungan kerja dan suasana kerja yang aman dan tentram.

Sedangkan indikator pengukuran kepuasan kerja (Afandi, 2018) adalah (1)pekerjaan; (2)upah; (3)promosi; (4)pengawas; (5)rekan kerja. Menurut Hasibuan (2012) indikator yang dapat digunakan dalam penelitian untuk mengukur kepuasan kerja adalah (1)menyenangi pekerjaan; (2)mencintai pekerjaan; (3)moral kerja; (4)prestasi kerja. Sedangkan Luthan (2010) menyatakan bahwa ada lima indikator yang dapat digunakan untuk mengukur kepuasan kerja, yaitu (l)pembayaran; (2)pekerjaan; (3)rekan kerja; (4)promosi kerja; (5)kepenyeliaan. Berdasarkan indikator yang telah dikemukakakn oleh para ahli, maka penelitian ini menggunakan indikator untuk engukur krpuasan kerja sebagai berikut: (1)pekerjaan; (2)aturan organisasi; (3)upah dan keuntungan; (4)rekan kerja; (5)tanggung jawab.

Adapun hipotesis penelitian ini adalah sebagai berikut:

a. Hipotesis $\mathrm{Nol}$

1. Tidak terdapat pengaruh variabel budaya kerja secara parsial terhadap variabel kepuasan kerja pegawai di Sekretariat Daerah Kabupaten Agam

2. Tidak terdapat pengaruh variabel disiplin kerja secara parsial terhadap variabel kepuasan kerja pegawai di Sekretariat Daerah Kabupaten Agam

3. Tidak terdapat pengaruh variabel Budaya kerja dan variabel disiplin kerja secara simultan terhadap variabel kepuasan kerja pegawai di Sekretariat Daerah Kabupaten Agam

b.Hipotesis Alternatif

1. Terdapat pengaruh variabel budaya kerja secara parsial terhadap variabel kepuasan kerja pegawai di Sekretariat Daerah Kabupaten Agam

2.Terdapat pengaruh variabel disiplin kerja secara parsial terhadap variabel kepuasan kerja pegawai di Sekretariat Daerah Kabupaten Agam

3. Terdapat pengaruh variabel Budaya kerja dan variabel disiplin kerja secara simultan terhadap variabel kepuasan kerja pegawai di Sekretariat Daerah Kabupaten Agam

\section{HASIL DAN PEMBAHASAN}

Adapun analisis data tahap pertama yang digunakan adalah analisis deskriptif yang menganalisis Total Capaian Responden yang didasarkan pada variabel penelitian. Adapun nilai TCR disajikan pada tabel 1 sebagai berikut:

Tabel 1. Nilai TCR Variabel Penelitian

\begin{tabular}{ccc}
\hline Variabel & Mean & TCR \\
\hline Budaya Kerja & 3,95 & 79,08 \\
Disiplin Kerja & 3,93 & 78,69 \\
Kepuasan Kerja & 3,99 & 79,81 \\
\hline
\end{tabular}

Sumber: Hasil Olah Data Penelitian 2021

Berdasarkan tabel 1, maka dapat dilihat bahwa rata-rata total capaian responden memiliki persentase yang lebih besar dari 50\%. Dengan adanya klasifikasi nilai yang telah ditentukan, maka variabel budaya kerja pegawai di Sekretariat Daerah Kabupaten Agam dinyatakan sudah baik dengan persentase $79,08 \%$. Untuk nilai disiplin kerja pegawai di Sekretariat Daerah Kabupaten Agam juga diklasifikasikan baik dengan persentase $78,69 \%$. Kepuasan kerja pegawai di Sekretariat Daerah Kabupaten Agam berdasarkan hasil total capaian responden juga diklasifikasikan sudah baik dengan persentase $79,81 \%$. Dengan demikian, dapat dinyatakan bahwa semua variabel dalam penelitian ini, memiliki total capaian responden yang sudah baik di Sekretariat Daerah Kabupaten Agam.

Uji yang dilakukan selanjutnya adalah uji asumsi klasik. Adapun uji asumsi klasik yang dilakukan berupa uji normalitas, uji multikolonieritas, uji autokorelasi dan uji heteroskedastisitas. Adapun hasil uji asumsi klasik tersebut dapat dilihat pada Gambar 1 dan 2 serta Tabel 2 dan 3.

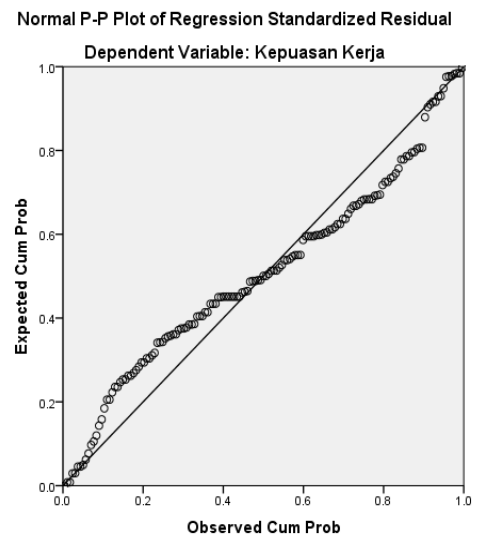

Gambar 1. Uji Normalitas

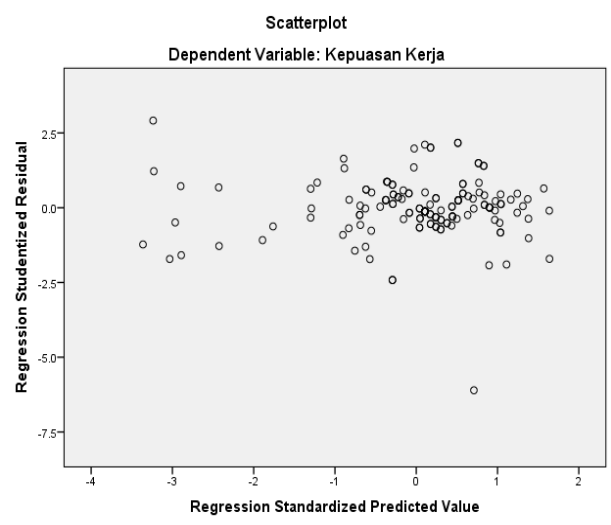

Gambar 2. Uji Heteroskedastisitas

Tabel 2. Uji Multiolonieritas

\begin{tabular}{|c|c|c|c|c|c|c|c|}
\hline \multicolumn{8}{|c|}{ Coefficients $^{a}$} \\
\hline \multirow[t]{2}{*}{ Model } & \multicolumn{2}{|c|}{$\begin{array}{l}\text { Unstandardized } \\
\text { Coefficients }\end{array}$} & $\begin{array}{l}\text { Standar- } \\
\text { dized } \\
\text { Coeffici- } \\
\text { ents } \\
\end{array}$ & \multirow[t]{2}{*}{$\mathrm{T}$} & \multirow[t]{2}{*}{ Sig. } & \multicolumn{2}{|c|}{$\begin{array}{l}\text { Collinearity } \\
\text { Statistics }\end{array}$} \\
\hline & B & $\begin{array}{l}\text { Std. } \\
\text { Error }\end{array}$ & Beta & & & $\begin{array}{l}\text { Tole- } \\
\text { rance }\end{array}$ & $\overline{\text { VIF }}$ \\
\hline $\begin{array}{l}\text { (Cons- } \\
\operatorname{tant})^{-}\end{array}$ & 6.606 & 1.919 & & 3.442 & .001 & & \\
\hline $\begin{array}{l}\text { Budaya } \\
\text { Kerja }\end{array}$ & .307 & .059 & .376 & 5.221 & .000 & .421 & 2.375 \\
\hline $\begin{array}{l}\text { Disiplin } \\
\text { Kerja }\end{array}$ & 297 & .043 & 499 & 6.923 & .000 & .421 & 2.375 \\
\hline
\end{tabular}

a. Dependent Variable: Kepuasan Kerja

Sumber : Hasil Olah Data Penelitian 2021

Tabel 3. Uji Autokorelasi

\begin{tabular}{cc}
\hline \multicolumn{2}{c}{ Runs Test } \\
\hline \multicolumn{2}{c}{ Unstandardized Residual } \\
\hline Test Value ${ }^{\mathrm{a}}$ & .00443 \\
Cases $<$ Test Value & 75 \\
Cases $>$ Test Value & 76 \\
Total Cases & 151 \\
Number of Runs & 73 \\
$z$ & -.571
\end{tabular}

Malini Syaftia Rahmawati dan Aldri Frinaldi 
Asymp. Sig. (2-tailed)

a. Median

Sumber : Hasil Olah Data Penelitian 2021

Berdasarkan gambar 1, dapat dilihat bahwa data terdistribusi dengan normal. Hal ini dapat dilihat dari adanya titik-titik yang berada dipenjang garis. Hal ini menyatakan bahwa data pada penelitian ini memenuhi syarat untuk dilakukan uji regresi. Pada gambar 2, dapat dilihat titik-titik menggambarkan data yang tersebar diatas angka nol pada sumbu Y. Hal ini juga terlihat bahwa titik-titik tersebut tidak membuat pola tertentu. Dengan begitu, dapat dinyatakan bahwa tidak terdapat masalah heteroskedastisitas.

Pada tabel 2, dapat dilihat bahwa nilai VIF lebih kecil dari 10. Selain itu, besarnya nilai tolerance juga lebih besar dari 0,10 . Hal ini menyatakan bahwa pada data penelitian, tidak terjadi permasalahan multikolonieritas antar variabel penelitian. Selanjutnya pada tabel 3, dapat dilihat bahwa nilai Asymp. Sig.(2tailed) memiliki nilai yang besar dari 0,05, yaitu sebesar 0.,568. Hal ini menyatakan bahwa pada data penelitian ini tidak terjadi autokorelasi, yang berarti tidak terjadi korelasi antara anggota observasi yang disusun menurut waktu dan tempat. Terpenuhinya 4 uji asumsi klasik diatas, maka hal ini menyatakan bahwa analisis regresi berganda dapat dilakukan.

Berdasarkan tahapan uji analisis regresi berganda, maka hasil uji t dapat dilihat pada tabel 4 berikut:

Tabel 4. Hasil Uji T variabel Xl dan X2 terhadap Y

\begin{tabular}{cccccc}
\hline \multicolumn{5}{c}{ Coefficients $^{\mathrm{a}}$} \\
\hline Model & $\begin{array}{c}\text { Unstandar- } \\
\text { dized } \\
\text { Coefficients }\end{array}$ & $\begin{array}{c}\text { Standar } \\
\text {-dized } \\
\text { Coeffi- } \\
\text { cients }\end{array}$ & T & Sig. \\
\cline { 2 - 5 } & $\mathrm{B}$ & $\begin{array}{c}\text { Std. } \\
\text { Error }\end{array}$ & Beta & & \\
\hline (Constant) & 6.606 & 1.919 & & 3.442 & .001 \\
$\begin{array}{c}\text { Budaya Kerja } \\
\text { Disiplin } \\
\text { Kerja }\end{array}$ & .307 & .059 & .376 & 5.221 & .000 \\
\hline
\end{tabular}

a. Dependent Variable: Kepuasan Kerja

Sumber : Hasil Olah Data Peelitian 2021

Berdasarkan data pada tabel 4, maka dapat dilihat bahwa secara parsial terdapat pengaruh budaya kerja terhadap kepuasan kerja dengan signifikansi sebesar 0,00. Hal ini menyatakan bahwa pengaruh $\mathrm{Xl}$ terhadap $\mathrm{Y}$ ini dapat dipercayai kebenarannya 100\%. Sedangkan untuk nilai Beta variabel Xl terhadap Y adalah sebesar 0,376. Selanjutnya juga dapat dilihat bahwa secara parsial terdapat pengaruh disiplin kerja terhadap kepuasan kerja dengan signifikansi sebesar 0,00. Hal ini menyatakan bahwa pengaruh Xl terhadap Y ini dapat dipercayai kebenarannya 100\%. Sedangkan untuk nilai Beta variabel Xl terhadap Y adalah sebesar 0,499.

Untuk menentukan besarnya masing-masing sumbangan pengaruh variabel independen terhadap variabel dependen, maka digunakan rumus Sumbangan Efektif (SE) yaitu SE = Betax $_{x}$ Koefisien Korelasi $i_{x y}$ x 100\%. Adapun hasilnya dapat dilihat pada tabel dibawah ini:

Tabel 5. Sumbangan Efektif Xl dan X2 terhadap Y

\begin{tabular}{cccc}
\hline Variabel & $\begin{array}{c}\text { Koefisien } \\
\text { Regresi (Beta) }\end{array}$ & $\begin{array}{c}\text { Koefisien } \\
\text { Korelasi (r) }\end{array}$ & $\begin{array}{c}\text { Sumbangan } \\
\text { Efektif (\%) }\end{array}$ \\
\hline $\mathrm{Xl} \rightarrow \mathrm{Y}$ & 0.376 & 0.756 & 28.4 \\
$\mathrm{X} 2 \rightarrow \mathrm{Y}$ & 0.499 & 0.785 & 39.2 \\
\hline \multicolumn{2}{l}{ Sumber: Hasil Olah Data Penelitian 2021 }
\end{tabular}

72 Malini Syaftia Rahmawati dan Aldri Frinaldi
Berdasarkan hasil perhitungan diatas, maka dapat dinyatakan bahwa persentase pengaruh disiplin kerja memiliki pengaruh yang lebih besar terhadap kepuasan kerja, yaitu sebagai 39,2\%. Sedangkan pengaruh budaya kerja terhadap kepuasan kerja adalah sebesar $28,4 \%$.

Analisis regresi yang dilakukan selanjutnya adalah uji $\mathrm{F}$ atau uji secara simultan. Adapun hasilnya dapat dilihat pada tabel 6 sebagai berikut:

Tabel 6. Uji F Variabel Xl dan X2 terhadap Y

\begin{tabular}{|c|c|c|c|c|c|c|}
\hline \multicolumn{7}{|c|}{ ANOVA $^{a}$} \\
\hline & Model & $\begin{array}{l}\text { Sum of } \\
\text { Squares }\end{array}$ & Df & $\begin{array}{l}\text { Mean } \\
\text { Square }\end{array}$ & $\mathrm{F}$ & Sig. \\
\hline \multirow{3}{*}{ l } & $\begin{array}{l}\text { Regres- } \\
\text { sion }\end{array}$ & 3065.456 & 2 & 1532.728 & 154.605 & $.000^{\mathrm{b}}$ \\
\hline & $\begin{array}{c}\text { Residu- } \\
\text { al }\end{array}$ & 1467.246 & 148 & 9.914 & & \\
\hline & Total & 4532.702 & 150 & & & \\
\hline
\end{tabular}

a. Dependent Variable: Kepuasan Kerja

b. Predictors: (Constant), Disiplin Kerja, Budaya Kerja Sumber: Hasil Olah Data Penelitian 2021

Berdasarkan data pada tabel 6, maka dapat dilihat bahwa nilai signifikansi hasil pengolahan data kecil dari 0,05 . Hal ini mengartikan bahwa terdapat pengaruh budaya kerja (Xl) dan disiplin kerja (X2) secara simultan terhadap kepuasan kerja (Y) yang pengaruh tersebut bersifat positif. Adanya pengaruh tersebut, dapat dipercayai $100 \%$.

Adapun besarnya kontribusi pengaruh pada hipotesisi ini dapat dilihat pada tabel 7 berikut:

Tabel 7. Kontribusi Variabel Xl dan X2 terhadap Y

\begin{tabular}{ccccc}
\hline \multicolumn{5}{c}{ Model Summary } \\
\hline \multirow{2}{*}{ Model } & $\mathrm{R}$ & $\begin{array}{c}\mathrm{R} \\
\text { Square }\end{array}$ & $\begin{array}{c}\text { Adjusted } \\
\text { R Square }\end{array}$ & $\begin{array}{c}\text { Std. Error of } \\
\text { the Estimate }\end{array}$ \\
\hline 1 & $.822^{\mathrm{a}}$ & .676 & .672 & 3.149 \\
\hline
\end{tabular}

a. Predictors: (Constant), Disiplin Kerja, Budaya Kerja

b. Dependent Variable: Kepuasan Kerja

Sumber: Hasil olah Data Penelitian 2021

Berdasarkan hasil olah data pada tabel 7, maka dapat dilihat bahwa untuk besarnya kontribusi X1 dan X2 terhadap Y dapat dilihat berdasarkan nilai adjusted $\mathrm{R}$ square sebesar 0,672 yang berarti budaya kerja dan disiplin kerja secara bersama-sama berpengaruh terhadap kepuasan kerja sebesar 67,2\%.

Budaya kerja merupakan suatu landasan yang berisi nilainilai yang terintegrasi dari pemahaman cara bekerja, norma, pola pikir dan perilaku setiap orang yang kemudian digunakan sebagai pedoman untuk menjalankan pekerjaan Berdasarkan analisis data yang dilakukan pada penelitian ini, secara posiitif, budaya kerja memiliki pengaruh terhadap kepuasan kerja pegawai di Sekretariat Daerah Kabupaten Agam. Hal ini berarti bahwa jika budaya kerja yang dimiliki oleh pegawai baik, maka akan meningkatkan kepuasan kerja pegawai. Budaya kerja yang baik seharusnya memang dapat mewujudkan adanya kebutuhan pegawai yang terpenuhi dalam bekerja oleh organisasi. Budaya kerja yang baik akan memberikan penilaian yang baik secara afektif dan kognitif, sehingga pegawai dapat memperhatikan perbandingan hal yang nyata terjadi dengan hal yang seharusnya terjadi. Adanya kepuasan kerja yang baik oleh seorang pegawai juga merupakan salah satu bentuk perwujudan adanya budaya kerja yang baik pula dalam organisasi tersebut. Berdasarkan keterangan dan hasil penelitian, maka dinyatakan bahwa hipotesis alternatif diterima. dengan kata lain terdapat pengaruh budaya kerja 
terhadap kepuasan kerja pegawai di Sekretariat Daerah Kanupaten Agam.

Hasil penelitian berikutnya menyatakan bahwa hipotesis alternatif diterima. adapun hipotesis tersebut menyatakan secara parsial, disiplin kerja memiliki pengaruh langsung terhadap kepuasan kerja pegawai di Sekretariat Daerah Kabupaten Agam. Pada dasarnya disiplin kerja merupakan bentu kesadaran dan kesediaan seorang pegawai untuk mematuhi aturan organisasi dan norma-norma sosial yang berlaku ditempat. Kesadaran yang dimaksud adalah adanya kesukarelaan seorang pegawai untuk menaati semua aturan dan sadar terhadap tugas dan tanggung jawabnya sebagai pegawai. Sedangkan kesediaan yang dimaksud adalah sikap atau perilaku pegawai yang sesuai dengan peraturan yag tertulis maupun tidak tertulis. Pegawai tidak hanya sekedar formalitas melaksanakan tugas dan tanggung jawabnya dikantor, namun juga harus mampu merasakan dan menikmati pekerjaannya, agar tidak merasa bosan dan lebih tekun dalam beraktivitas. Para pegawai akan lebih senang apabila dalam pekerjaannya dapat dilakukan dengan mudah. Hal tersebut karena pegawai bekerja sesuai dengan peraturan dan prosedur kerja yang ada. Dengan adanya disiplin yang tinggi, maka kerja para pegawai akan meningkat. Hal tersebut dapat dilihat dari kerajinan mereka untuk melaksanakan tanggung jawab sebagai pegawai disuatu organisasi. Besarnya rasa taggung jawab yang dirasakan pegawai atas tugas dan kewajibannya akan mendorong gairah kerja, semangat kerja dan terwujudnya organisasi. Adapun bentuk tanggungjawab yang besar tersebut atas pekerjaannya akan memberikan kepuasan kerja bagi pegawai itu sendiri.

Hasil penelitian selanjutnya juga menyatakan bahwa hipotesis alternatif diterima, dimana budaya kerja dan disiplin kerja memiliki pengaruh secara simultan terhadap kepuasan kerja. adapun kekuatan kedua variabel secara bersama-sama terhadap kepuasan kerja memiliki kekuatan sebesar 67,2\%. Kepuasan kerja adalah cerminan perasaan pegawai terhadap pekerjaan yang dilakukannya. Pegawai harus bisa menikmati pekerjaan yang dilakukannya. Oleh karena itu, agar adanya efektivitas dan efisiensi dalam bekerja yang memberikan kepuasan kepada pegawai, maka organisasi harus memiliki budaya kerja dan disiplin kerja yang mendukung pekerjaan pegawai.

\section{KESIMPULAN}

Berdasarkan penelitian yang telah dilakukan, maka dapat dinyatakan bahwa secara parsial maupun secara simultan, variabel budaya kerja dan disiplin kerja memiliki pengaruh terhadap kepuasan kerja pegawai di Sekretariat Daerah Kabupaten Agam. Secara Parsial, variabel disiplin kerja memiliki kontribusi yang lebih besar terhadap kepuasan kerja dibandingkan variabel budaya kerja. Adapun besar pengaruh variabel budaya kerja terhadap kepuasan kerja hanya sebesar $28,4 \%$, sedangkan besar pengarush disiplin kerja terhadap kepuasan kerja pegawai adalah $39,2 \%$. Selanjutnya, variabel budaya kerja dan disiplin kerja secara bersama-sama memiliki pengaruh terhadap kepuasan kerja sebesar $67,2 \%$.

\section{UCAPAN TERIMA KASIH}

Penulis mengucapkan terima kasih kepada pihak Jurnal Public Policy yang telah memberikan kesempatan kepada penulis untuk mengajukan artikel penulis pada jurnal ini.
Selain itu juga melakukan review terhdap artikel ini, sehingga artikel ini menjadi lebih baik. Kemudian, penulis juga mengucapkan terima kasih atas semua pihak yang telah terlibat dalam menyelesaikan artikel ini, mulai dari pengumpulan data, pengolahan data hingga dalam penyelesaian artikel ini.

\section{REFERENSI}

Afandi, P. (2018). Manajemen Sumber Daya Manusia. Pekan Baru: Penerbit Zanafa Publishing.

Afianto, I. D., \& Utami., H. N. (2017). Pengaruh Disiplin Kerja dan Komunikasi Organisasi terhadap Kepuasan Kerja dan Kinerja Karyawan (Studi pada Karyawan Divisi Marketing PT. Victory International Futures Kota Malang). Jurnal Administrasi Bisnis, 50(6). Diambil dari http://administrasibisnis.studentjournal.ub.ac.id.

Chan, S. C. H. (2019). Participative leadership and job satisfaction: The mediating role of work engagement and the moderating role of fun experienced at work. Leadership e Organization Development Journal. https://doi.org/10.1108/LODJ-06-2018-0215

Creswell, J. W. (2010). Research Design: Pendekatan Kualitatif, Kuantitatifdan Mixed. Yogyakarta: Pustaka Pelajar.

Dwiyono, Y. (2017). The Effect of leadership style, professional competence, and work didscipline toward work effectiveness. International Conference on Education and Technology (2017 ICEduTech), 144, 126-130.

Fathoni, A. (2006). Manajemen Sumber Daya Manusia. Jakarta: PT Rineka Cipta.

Frinaldi, A. (2014). Pengaruh Budaya Kerja Pegawai Negeri Sipil Terhadap Pelayanan Publik di Dinas Catatan Sipil dan Kependudukan Kota Payakumbuh. Humanus, 13(2), 180-192. https://doi.org/10.24036/jh.vl3i2.4727

Frinaldi, A. (2017). Mengelola Budaya Organisasi dan Budaya Kerja. Padang: UNP Press.

Frinaldi, A., \& Embi, M. A. (2013). Budaya Kerja 'Giot Ipas' dalam Kalangan Pegawai Negeri Sipil Etnik Mandailing (Studi Kasus pada Kabupaten Pasaman Barat, Provinsi Sumatera Barat). Jurnal Ilmiah Ilmu-Ilmu Humaniora.

Frinaldi, A., \& Putri, N. E. (2020). The influence of Work Culture and Work Quality on Service Quality in 50 Kota Regency, West Sumatera. Advances in Social Science, Education and Humanities Research, 50, 361-370.

Garg, K., Dar, I. A., \& Mishra, M. (2017). Job Satisfaction and Work Engagement: A Study Private Sector Bank Managers. Advances in Developing Human Resource, 1-14.

Gorda, I. (2004). Manajemen Sumber Daya Manusia (Revisi Cetakan Kedua). Denpasar: Astabrata.

Hasibuan, M. P. (2013). Manajemen Sumber Daya Manusia. Jakarta: PT Bumi Aksara.

Hofstede, G. (1997). Culture and Organization. Software on Mind. Intercultural Coperation and Its Importance for Survival. New York: Mcgraw-Hill.

Judge, T. A., HM, W., Mueller, M. K., \& C.L, H. (2017). Job Attitudes, Job Satisfaction, and Job Affect: A Century of Continuity amd of Change. Advance online publication. https://doi.org/10.1037/apl0000181

Khuzaeni, M. I., Djumahir, \& Solimun. (2013). The influence of Work Culture, Work Stress to the Job Satisfaction and Employees Performance in the State Treasury Service in 
Jakarta, Indonesia. IOSR Journal of Business and Management, 9(2). Diambil dari www.iosrjournal.org

Lee, A., Willis, S., \& Tian, A. W. (2017). Empowering leadership: A meta-analytic examination of incremental contribution, mediation, and moderation. Journal of Organizational Behavior, 39(3), 1-20.

Luthans, F. (2013). Organizational Behaviour (McGraw Hill Education (Terjemahan)). Jakatra: PT Indeks.

Mangkunegara, A., A. A. (2011). Manajemen Sumber Daya Manusia Perusahaan (Edisi Revisi, Cetakan Kesepuluh). Bandung: PT Remaja Rosdakarya Offset.

Nawawi, H. (2006). Evaluasi dan Manajemen Kinerja di Lingkungan Perusahaan dan Industri. Yogyakarta: Gadjah Mada University Press.

Prayogi, M., \& Nursidin, M. (2019). Pengaruh Kompetensi dan Disiplin Kerja terhadap Kinerja Karyawan. Jurnal Festifal Riset Ilmiah Manajemen dan Akuntansi 1, 11, 1-5.

Strauss, S., \& Sayles, S. (2012). Kepemimpinan dalam Organisasi. Jakarta: Prenhallindo.

Sugiyono, S. (2013). Metode Penelitian Kuantitatif, Kualitatif dan ReD. Bandung: Alfabeta.

Sugiyono, S. (2017). Metode Penelitian Kuantitatif, Kualitatif dan R $\mho D$. Bandung: Alfabeta.

Susanty, A., \& Baskoro, S. W. (2013). Pengaruh Motivasi Kerja Dan Gaya Kepemimpinan Terhadap Disiplin Kerja serta Dampaknya pada Kinerja Karyawan (Studi Kasus Pada PT. PLN (Persero) APD Semarang). Jati Undip: Jurnal Teknik Industri, 7(2), 77-84. https://doi.org/10.12777/jati.7.2.77-84

Weiss, H. M. (2002). Deconstructing job satisfaction: Separating evaluation, beliefs and effective experience. Human Resource Management review, 12, 173-195. 